\title{
BLACK SEA REGION IN THE STRATEGY OF THE EUROPEAN UNION IN THE XXI CENTURY
}

\author{
(c) Dmitry I. Uznarodov, Igor M. Uznarodov
}

\author{
Southern Scientific Center, Russian Academy of Sciences, \\ Rostov State University of Economics, Rostov-on-Don, Russian Federation \\ uzn-dmitrij@yandex.ru, iguz2010@yandex.ru
}

The article considers the policy of the European Union in the Black sea region in the XXI century as a part of the general policy of the EU in the post-Soviet space. The policy in the region is analyzed by the example of its main components - the European neighborhood policy, the Eastern partnership, as well as taking into account the policy in the South Caucasus. The article also discusses reasons for the deterioration of relations between Russia and European Union in connection with the policy of the EU in the Black sea region. Attention is drawn to the fact that it happened after the activation of the EU policy in the post-Soviet space, what inevitably came into conflict with foreign policy priorities of Russian Federation. It is concluded that in spite of a fairly active policy in the region, the European Union failed to involve in its orbit all states of the region. It is noted that today the EU continues to struggle for strategic influence in the region. Therefore, there remain serious contradictions between Russia and the European Union, and therefore we should not expect the improving relations between them in the near future.

Key words: European Union; Russia; Black Sea region.

\section{[Д.И. Узнародов, И.М. Узнародов Черноморский регион в стратегии Европейского Союза в XXI веке]}

Рассматривается политика Европейского Союза в Черноморском регионе в XXI веке как часть общей политики EC на постсоветском пространстве. Политика в регионе анализируется на примере её основных составляющих - Европейской политики соседства, Восточного партнёрства, а также с учётом политики на Южном Кавказе. Также в статье рассматриваются причины ухудшения отношений между Россией и Евросоюзом в связи с политикой последнего в Черноморском регионе. Обращено внимание на то, что это произошло после активизации политики ЕС на постсоветском пространстве, что неизбежно вступало в противоречие с приоритетами внешней политики Российской Федерации. Делается вывод, что, несмотря на проведение достаточно активной политики, Евросоюзу не удалось вовлечь в свою орбиту все государства региона. Отмечается, что и сегодня ЕС продолжает борьбу за стратегическое влияние в регионе. Поэтому сохраняются серьёзные противоречия между Россией и Евросоюзом. В исследовании доказано, что применение политического, межкультурного диалога стран, преодоление идеологического вакуума, способствуют развитию общества, достойного современного человека.

Ключевые слова: Европейский Союз; Россия; Черноморский регион, Восточное партнерство, Европейская политика, отношения с Россией, кризис на Украине.

Dmitry I. Uznarodov - candidate of Political Sciences, Researcher, Laboratory of Studying of Cossacks, Southern Scientific Center, Russian Academy of Sciences, Rostov-on-Don, Russian Federation.

Узнародов Дмитрий Игоревич - кандидат политических наук, научный сотрудник, лаборатория казачества, Южный научный центр Российской академии наук. г. Ростов-на-Дону, Российская Федерация.

Igor M. Uznarodov - PhD, Doctor of Historical Sciences, Head of the Department of World Economics, Politics and Globalization, Rostov State University of Economics. Rostov-on-Don, Russian Federation.

Узнародов Игорь Миронович - доктор исторических наук, профрессор, заведующий кафредрой мировой политики и глобализации. Ростовский государственный экономический университет. е. Ростов-на-Дону, Российская Федерация. 
Relations between the European Union and Russia are of great importance for the European continent in the $X X I$ century. Even taking into account their substantial deterioration and the introduction of mutual sanctions, the EU remains in first place as a trading partner of Russia and an investor in the Russian economy. Russia is still the third largest trade and economic partner of the EU. As for the political dialogue, it also retains its relevance in responding to the challenges of the XXI century, including solving problems of European security and international terrorism.

At the same time, the deterioration of bilateral relations is multifactorial in nature and is associated not only with the crisis in the Ukraine. In particular, the new foreign policy tasks of the EU in Eastern Europe and in the Black Sea region contributed to this development, the solution of which seriously affected the vital interests of Russia. The purpose of the study is to consider how the policy of the European Union in the Black Sea region in the XXI century affected relations with Russia.

In the 1990s, the European Union showed increased attention to the Black Sea region, which was explained by its geographic location on the path to the energy resources of the states of the Caspian region, Central Asia and Iran. At the same time, a project was initiated to create a transport corridor from Europe to Central Asia, and plans for the construction of oil and gas pipelines emerged [2, p. 375-379]. However, the matter did not come to major economic projects, and the Black Sea direction of international politics was not significant enough for Brussels at that time.

In the 1990s, relations between Russia and the EU developed very successfully. The most important result was the signing of the Partnership and Cooperation Agreement (PCA) in 1994. Later, despite the existing problems, the idea of strategic partnership and the creation of four common spaces of in-depth cooperation emerged [5, p. 184-192; 384-396]. Of course, the interaction of the European Union with Russia assumed that its interests in the post-Soviet space would be taken into account.

After the disintegration of the USSR, the post-Soviet space gained particular importance for the new Russia. In the "Concept of the Foreign Policy of the Russian Federation" (1993), the priority was the formation of fundamentally new, equal and mutually beneficial relations of Russia with the participants of the CIS and other neighboring countries. This was considered one of the main directions of foreign policy activity and the most important condition for the further development of Russia [3, p. 19-50]. This approach was based on the existence of the Soviet military-strategic and socio-economic space, economic relations and relations between the regions. Because of disintegration, a significant number of Russian citizens turned out to be outside their country, and many Russian enterprises retained partners who now represented the new independent states.

The document also emphasized that some neighboring states are trying to use the collapse of the USSR to strengthen their positions, to prepare plans for the formation of certain communities under a national or religious banner. Accordingly, there was a threat to the security of Russia, its economic interests, as well as the interests of Russians, who lived in the former Soviet republics [1, p. 26-27].

In 2000, in connection with the election of V.V. Putin, a new president adopted a new "Foreign Policy Concept of the Russian Federation" in which priorities immediately after confirming the importance of developing good-neighborly relations and strategic partnership with all CIS member states, spoke about relations with European states as a traditional priority direction of Russian foreign policy, emphasized the key meaning of relations with the European Union. The latter saw one of the most important political and economic partners with which Russia planned intensive, stable and long-term cooperation, devoid of any market fluctuations [1, p. 109-121].

In September 2001, speaking in Berlin to the Bundestag deputies, V.V. Putin confirmed that the European direction was not randomly placed in second place among the pri- 
orities of Russian foreign policy. He noted that Europe would be able to permanently strengthen the reputation of a powerful and independent center of world politics if it combines its human, territorial and natural resources with Russia's economic, cultural and defense potential [19, p. 454].

In May 2003, the idea of creating four common spaces of in-depth cooperation between the European Union and Russia was approved. Two years later, the action plans were agreed, which implied the creation of common spaces of the economy, freedom, security and justice, external security, science, education and culture. This laid the foundation for a strategic partnership [13].

However, at about the same time, a slowdown in the development of political and strategic interaction between Russia and the European Union begins. The latter faced a choice: either to deepen cooperation with our country, to create common European spaces for mutual benefit, or to give preference to economic and political expansion into the former Soviet republics and former socialist states (by accepting them into the EU). The choice was made in favor of the second option, although he clearly did not take into account either the economic or the geopolitical interests of Russia. It seems that the position of the US leadership, which did not wish to accept the independent course of our country in the international arena, played a significant role in this decision [16, p. 237-238].

In 2003, the European Union announced the European Security Strategy, which contained significant changes in the international activities of the European Union in connection with its forthcoming expansion. The country said that by uniting 25 states with a population of over 450 million people producing a quarter of the world's national product, the EU inevitably becomes a global player, and, accordingly, should be ready to share responsibility for security in the world and its better future.

At the same time, the document drew attention to the fact that the EU enlargement, scheduled for 2004, brings the union closer to crisis regions. Therefore, one of the main tasks was to create rings of well-governed countries to the east of the European Union and along its borders in the Mediterranean, with which it could maintain close cooperation [3, $\mathrm{p}$. 29-36]. Accordingly, it was supposed to change the policy towards the states of the Black Sea region.

Unfortunately, after the enlargement of the $E U$, its relations with Russia entered a stage of stagnation. In addition, according to N.P. Shmeleva and V.P. Fedorov, the European Union divided countries into friends and foes, and Russia ended up in the second group [18, p. 42]. This circumstance corresponded to the changes that occurred in the international arena.

In an interview with the Italian scientific and political magazine "Limes", well-known scholar and expert in the field of international relations, S.A. Karaganov noted that in the conditions of the outgoing unipolar system in the world, the West was ready to hold onto its crumbling positions at any cost. In Russia, in the second half of the 2000s, it became clear that it would not be possible to reach an agreement on ending the Neo-Weimar expansion of the Western unions into territories that were considered vital for security from Moscow. Therefore, Russia has prepared - it has carried out a successful military reform both in words and by deeds it stated that it will not tolerate the orders established by the West in the 1990s [25].

After the enlargement, the European Union developed and approved in May 2004 a new strategy called the European Neighborhood Policy (ENP) [23], which envisaged interaction with neighboring countries in order to create a security zone and welfare on the borders of the $\mathrm{EU}$, as well as raising the profile of the Union's role in resolving regional conflicts. Financial support was provided for the ENP in order to develop a market economy and create an attractive business climate for European investors. The scope of the new pol- 
icy included Belarus, Moldova, Ukraine, Azerbaijan, Armenia, Georgia, and Bulgaria, Romania and Turkey were considered candidates for joining the Union.

After the accession of Bulgaria and Romania to the EU in January 2007, the Union's policy in the Black Sea region began to acquire new outlines, as the European Commission's document entitled "Black Sea Synergy" was evidenced. He supplemented the ENP, but its content largely repeated the program of activities of the Black Sea Economic Cooperation Organization (BSEC). The new intention was to build special relations with Armenia, Azerbaijan, and Georgia.

The synergetic approach of the new strategy consisted of three main areas: 1) relations with the Republic of Turkey as a candidate for EU membership; 2) relations with the post-Soviet countries, in particular, Azerbaijan, Armenia, Georgia, Moldova and Ukraine; 3) a policy aimed at establishing a strategic partnership with Russia [12]. In fact, within the framework of the synergistic approach, there was also a fourth link of countries (Bulgaria, Greece, Romania), whose main task as EU members was to actively help implement the initiatives laid down in the framework of the developed strategy.

As for the direction of the Black Sea synergy affecting the relations of the EU and Turkey, its special significance was associated with a certain period of "cooling" in TurkishEuropean relations in 2007. In 2007, Germany and France opposed Turkey's accession to the EU. In January 2007, Nicolas Sarkozy in the status of presidential candidate stated the following: "Europe has certain borders, and not all countries can become its full members, this also applies to Turkey, which has no place in the European Union; Unlimited expansion of the EU can lead to the destruction of the European political union "[14].

One of the traditional "stumbling-blocks" in relations between the EU and Turkey is the recognition of the Armenian Genocide in the Ottoman Empire in 1915, as well as the issue of Northern Cyprus, in whose territory Turkish military forces have been located since 1974. It should be noted that, despite the existence of the two issues that are problematic for the negotiation process, there are issues of a deeper and more complex nature that have a direct impact on the prospects for the accession of the Turkish Republic to the EU. First of all, we are talking about the gradual transition of Turkey over the past thirty years to the political doctrine of "Neo-Ottmanism", the main idea of which is to establish closer cooperation with the former colonies of the Ottoman Empire, as well as to pursue a policy aimed at integrating Turkic-speaking and Arab States. As for domestic policy, here the doctrine of "NeoOttmanism" finds its manifestation, in particular, in the presence in the country's passport of special columns of religious affiliation, as well as an increase in the number of special Islamic schools over the past two decades [6].

The last tension in relations between Turkey and the EU is dated in the summer of 2016, when an attempted coup took place in the Turkish Republic, which was not successful. As a result, an armed rebellion killed 238 people, injured about 3 thousand people, 13 thousand people were arrested, which caused criticism of the EU regarding the reaction of the Turkish authorities to the events [17]. The prospects for Turkey's accession to the EU, as well as the introduction of a visa-free regime between the EU and Turkey, have practically come to naught.

Considerable importance is also attached to the issue of cooperation between the European Union and the largest international association of the "Big Black Sea Coast" - the organization of the Black Sea Economic Cooperation. In June 2007, following the Istanbul BSEC Summit, the European Commission received observer status in the organization. In addition, a joint declaration was adopted, according to which the leaders of the BSEC member states stressed "the importance of establishing strategic relations between the two organizations" [22]. On February 14, 2008, a meeting of the Council of Ministers of Foreign Affairs of the organization, as well as a joint meeting of the heads of the foreign affairs agencies of the EU and the BSEC, was held in Kiev, during Ukraine's chairmanship of the 
BSEC. As a result of these events, the Black Sea Synergy was recognized as a key tool in strengthening cooperation in the Black Sea region. A final statement was also adopted, in which the BSEC member states were in favor of establishing closer cooperation between the two organizations in various fields. The only state that did not support the statement was Russia, which expressed itself in favor of the more significant role of the BSEC on the basis of an equal dialogue with the European Union.

It became clear that the BSEC has a role to play as an object of the EU regional policy, and not an equal partner. Russia offered cooperation primarily in the economic sphere, and the EU considered it necessary to pay more attention to resolving the so-called "frozen conflicts" in Abkhazia and South Ossetia. Thus, cooperation within the Big Black Sea region has become a problematic issue in relations between Russia and the European Union, and Russian representatives refused to write the Joint Statement proposed by the EU as a common initiating [9]. As a result, Western European diplomacy has embarked on deepening relations with the countries of the region without our country.

Later, the European Parliament also expressed its attitude towards the Black Sea region. On January 20,2011, its deputies approved a resolution on the EU strategy regarding the Black Sea region. The main goal of the strategy is to strengthen its influence in the region through integration with its member countries. The document noted the insufficient activity of the European Commission in the region, but at the same time emphasized its strategic importance, while the Black Sea itself was declared "partially internal" for the European Union.

Special attention in the statement is devoted to security issues in the Black Sea region. Conflicts in Abkhazia, South Ossetia and Transnistria are called "the main security challenges for all countries of the black-sea coast." Based on this, parliamentarians called on the EU leadership to take the lead in negotiations and peace processes aimed at resolving these conflicts. At the same time, Abkhazia and South Ossetia in the text of the strategy are designated as "occupied territories", which cannot be considered otherwise as an attack towards the Russian Federation, which recognized their independence. Approximately an expressed statement of concern to the European Parliament about the extension of the stay of the Russian fleet in the Crimea also can be assessed that way [24].

In view of the above, it should be emphasized that, due to its geographic location, the Black Sea for many centuries had a special interest of Russia, and as the geopolitical, economic and energy role of the Black Sea region increased, its significance for our country only increased.

Therefore, in Russia, the documents of various EU bodies relating to the Black-Sea region were perceived with caution. After all, according to the "Concepts of the Foreign Policy of the Russian Federation" (2008 and 2013), the post-Soviet space, which included this region, remained the main priority for our country $[10 ; 11]$.

It appears that behind the declarations on the need to promote economic reforms and democracy in the partner countries, with which the EU was active, there was a desire of Brussels to withdraw post-Soviet states from the sphere of Russian influence and to carry out geo-economic expansion into their territories.

In the end, the attempts of the European Union to assert its strategic influence in the Black Sea region became one of the reasons for the growth of political tension in the Ukraine. This was manifested in the support of the coup d'état that took place there in February 2014 and led to a sharp aggravation of relations between Russia and the countries of the West, followed by mutual sanctions. It should be noted that in parallel with the formation of EU policy in the Black Sea region, an anti-Russian campaign unfolded in the West. Under the pressure of American strategists, the anti-Russian course received increasing support in the member countries of the European Union. The activities of the GUAM group, es- 
tablished in 1999 on the initiative of Washington in Georgia, Ukraine, Azerbaijan and Moldova, were intensified.

The next step on this path was the Eastern Partnership project, approved in 2009 and continuing the European Neighborhood Policy. The official objective of the project was to create conditions for the political and economic integration of the European Union with Azerbaijan, Armenia, Belarus, Georgia, Moldova and the Ukraine. In case of successful implementation of the relevant reforms, it was planned to conclude bilateral agreements that were supposed to facilitate the integration of the participating countries into the European space. In the future, the possibility of negotiations on a new Association Agreement with the EU was proposed [21].

Within the framework of the project, it was supposed to include the Kalingrad region in the sphere of influence of the $\mathrm{EU}$, as well as to determine measures for the organization of alternative energy supply. Russian diplomats and experts interpreted these plans as an attempt to weaken Russia's position in Eastern Europe and remove the CIS countries from Russian influence [4, p. 380-397].

S.A. Zabelin notes that due to the global financial and economic crisis of 2008-2009 the Eastern Partnership did not receive real support at first. But after the promotion of the Southern Corridor project (supplies of Caspian gas to Europe via Turkey, bypassing Russia), the European Union returned to this idea. At the European Summit of the Eastern Partnership, which was held in 2011 in Warsaw, noted the outlined progress in economic cooperation between the EU and the participating countries, despite the difficulties due to the crisis. The next step was the question of creating a free trade zone with the participating countries [7, p. 46-48].

In June 2016, Brussels unveiled the European Union's Global Strategy on Foreign and Security Policy, in which the spatial vectors of the direct interests of the European Union are clearly identified. In the eastern direction, they extend to Central Asia inclusively. Thus, the EU confirmed its plans to create a favorable trade and economic periphery in the postSoviet space. The territory of Russia is also considered as a periphery.

With regard to the Eastern Partnership countries, it is supposed to use association agreements to increase the stability of their eastern neighbors and to defend their right to "freely determine" their approach to the EU. Stability refers to the ability to resist our country and the ability to leave its sphere of influence. It turns out that the EU denies Russia the right to have its interests in the post-Soviet space, but it does not hide its interest in trade and in the resources of these territories.

Relations with Russia are presented in the document as a key strategic challenge for the EU. It is emphasized that the Union "does not recognize" the "illegal annexation" of Crimea by Russia and "does not accept" the destabilization of the eastern Ukraine. It is obvious that such a position is connected with the Russian resistance to the plans of the European Union for moving eastward. At the same time, the EU is ready for "selective interaction" with Russia on issues of mutual interest [26].

In 2016, a new foreign policy concept was also approved in the Russian Federation. Its priority direction remains the development of bilateral and multilateral cooperation with the CIS member states and the further strengthening of the integration structures operating in the CIS with Russian participation. The key task was considered to deepen and expand integration within the framework of the Eurasian Economic Union, including with the Republic of Armenia. Among Russia's priorities remained the promotion of the formation of the Republic of Abkhazia and the Republic of South Ossetia as modern democracies, the strengthening of their international positions, the provision of reliable security and socioeconomic recovery.

The interaction of Russia with partners in the Black Sea and Caspian regions was planned to be built taking into account the commitment to the goals and principles of the 
BSEC Charter, and also taking into account the need to strengthen the cooperation mechanism of the five Caspian states on the basis of their collective decisions.

The document noted that the geopolitical expansion carried out by NATO and the European Union with the reluctance to embark on the implementation of political statements on the formation of a pan-European system of security and cooperation, caused a serious crisis in relations between Russia and Western states. At the same time, Russian policy in the Euro-Atlantic region in the long term is focused on the formation of a common space of peace, security and stability based on the principles of the indivisibility of security, equal cooperation and mutual trust [12].

A comparison of the basic documents of the European Union and Russia, in particular, their policies regarding the countries of the Black Sea region, allows us to conclude that serious contradictions and the impossibility of improving relations between the parties in the near future remain. As the Director of the Institute of Europe, RAS, Corresponding Member of the RAS A.A. Gromyko and Professor S. Biskop from the Royal Institute of International Relations in Brussels, at present Russia is represented throughout the collective West exclusively in a negative context as a threat to peace and stability. It is no longer considered a strategic partner of the European Union, although it is still recognized as a strategic player. At the same time, there is a high probability that acute competition and protectionism will determine the economic relations between Russia and the EU in the post-Soviet space [27, p. five].

So, the activation of the EU in the Black Sea region is observed after a fundamental change in its course in favor of political and economic expansion to the east. At the same time, attempts are being made to involve the independent states of the post-Soviet region in their sphere of influence. This happened both within the framework of the "European Neighborhood Policy" program and within the framework of the "Eastern Partnership" program.

Relations between Russia and the EU began to deteriorate after the latter stepped up its activities in the post-Soviet space. The EU leadership could not fail to understand that such a policy conflicts with the priorities of Russia's foreign policy. It seems that heightened activity towards the states of the South Caucasus, along with other factors, influenced political relations with Russia, contributing to their deterioration. At the same time, in the face of increasing competition for influence in the Black Sea region as a whole and in the South Caucasus in particular, the task of developing an integral strategy of the Russian Federation in the region, calculated for a long-term perspective, becomes very relevant.

The relevance of human development Russia determines the social significance of humanization issues, the importance of the development of personality, necessary for the full improvement of society. The study proved that the use of intercultural dialogue of countries, overcoming the ideological vacuum, contribute to the development of a society worthy of modern man.

\section{Лumepamypa}

1. Внешняя политика и безопасность современной России. 1992-2002. Хрестоматия в четырёх томах / редактор-составитель Т.А. Шаклеина. Том IV. Документы. М.: Московский государственный институт международных отношений (У) МИД России, Российская ассоциация международных исследований, АНО «ИНО-Центр», 2002. $538 \mathrm{c}$.

2. Гаджиев К.С. Геополитика Кавказа. М.: Международные отношения, 2003. 464 с.

3. Европейская стратегия безопасности. Безопасная Европа в лучшем мире. Люксембург: Бюро официальных публикаций Европейских Сообществ, 2009. 43 с.

4. Европейский Союз в XXI веке: время испытаний / под ред. О.Ю. Потемкиной // отв. ред. Н.Ю. Кавешникова, Н.Б. Кондратьевой. М.: Весь Мир, 2012. 656 с. 
5. Европейский Союз на пороге XXI века: выбор стратегии развития // под ред. Ю.А. Борко и О.В. Буториной. М.: Эдиториал УРСС, 2001. 472 с.

6. ЕС - Турция: тяжелый сон об интеграции // Радио «Свобода». 2013. 21 ноября. URL: https://www.svoboda.org/a/25174310.html (дата обращения: 11.04.2018).

7. Забелин С.A. Политика ЕС в отношении постсоветских стран Причерноморья // Большое Причерноморье: противоречия и стратегические решения для России / под ред. А.А. Языковой. Доклады Института Европы РАН. № 324. М.: ИЕ РАН, 2016.

8. Забелин C.A. Страны Причерноморья в контексте европейской политики соседства. European Geopolitical Forum. 2010. 13 июля. URL: http://gpfeurope.ru/upload/iblock/34c/prichiny-vozniknovenya-zeli-politiky-evropejskogososeda.pdf (дата обращения: 12.04.2018).

9. Колобов О.А., Краснов Д.В. «Черноморская синергия» Европейского Союза как новая инициатива регионального сотрудничества // Вестник Нижегородского университета им. Н.И. Лобачевского. 2009. № 2. С. 201-204.

10.Концепция внешней политики Российской Федерации. 2008. URL: http://www.kremlin.ru/acts/news/785 (дата обращения: 03.04.2018).

11. Концепция внешней политики Российской Федерации. 2013. URL: http://www.mid.ru/foreign_policy/official_documents/asset_publisher/CptlCkB6BZZ29/content/id/122186 (дата обращения: 03.04.2018).

12. Концепция внешней политики Российской Федерации. 2016. URL: http:// www.mid.ru/foreign_policy/news/-/asset_publisher/cKNonkJE02Bw/content/id/2542248 (дата обращения: 03.04.2018).

13. Россия - Европейский Союз: на пути к четырём общим пространствам. Доклады Института Европы. В 2 частях. Ч. 1. № 224; Ч.2. № 225. // под ред. Д.А. Данилова. М.: Русский сувенир, 2008.

14. Саркози. Турции нет места в ЕС // Издательский дом «Коммерсантъ». 2007. 14 янв.

15. Хафризоглу P. Турцию не интересует вопрос вступления в ЕС - президент // Новостное агентство «Trend». 2015. 24 янв. URL: https://www.trend.az/world/turkey/2356772.html (дата обращения: 14.04.2018).

16. Узнародов И.М. Запад после Второй мировой войны: тенденции развития. Ростовна-Дону: СКНЦ ВШ ЮФУ, 2014. 264 с.

17. Число задержанных после мятежа в Турции увеличилось до 26 тыс. человек // Росбизнесконсалтинг. 2016. 4 авг.

URL: https://www.rbc.ru/rbcfreenews/57a264db9a794779a4ef7716?from=newsfeed (дата обращения: 11.04.2018).

18. Шмелёв Н.П., Фёдоров В.П. Евросоюз - Россия: мера сотрудничества. Доклады Института Европы РАН. № 275. М.: Русский сувенир, 2012. 58 с.

19. Шрёдер Г. Решения. Моя жизнь в политике: пер. с нем. М.: Европа, 2007. 552 с.

20. Black Sea Synergy. A New Regional Cooperation Initiative. Brussels, 11.04.2007. URL: http://ec.europa.eu/world/enp/pdf/com07_160_en.pdf (дата обращения: 4.04.2018).

21. Council of the European Union. Joint Declaration of the Prague Eastern Partnership Summit. Prague, 7 May 2009. Brussels, 7 May 2009. 8435/09 (Presse 78). 11 p.

22. Declaration on the Occasion of the Fifteenth Anniversary Summit of the Black Sea Economic Cooperation. Istanbul, 25.06.2007. URL: http://www. bsecorganization.org/documents/declaration/summit/Reports/Istanbul\%202007.pdf (дата обращения: 16.04.2018).

23. European Neighbourhood Policy. Strategy Paper. Brussels, 12.05.2004. COM (2004) 373 final. $35 \mathrm{p}$.

24. European Parliament Resolution of 20 January 2011 on an EU Strategy for the Black $\begin{array}{llll}\text { Sea 2010/2087I URL: } & \text { (INI). }\end{array}$ http://www.europarl.europa.eu/sides/getDoc.do?type=TA\&reference=P7-TA-20110025\&language=HR (дата обращения: 05.04.2018). 
25. La vittoria della Russia e il nuovo concerto delle nazioni. Limes. 2017. №2. URL: http://karaganov.ru/content/images/uploaded/44fbfe8472ad2240e43a8b3b9072da08.pdf (дата обращения: 17.04.2018).

26. Shared Vision, Common Action: A Stronger Europe. A Global Strategy for the European Union's Foreign and Security Policy. Brussels, 2016. URL: https://eeas.europa.eu/sites/eeas/files/eugs_review_web.pdf (дата обращения: 09.04.2018).

27. The EU Global Strategy: Implications for Russia / Institute of Europe, Russian Academy of Sciences; Egmont - The Royal Institute for International Relations. Ed. by Olga Potemkina. M., 2017. 90 p.

\section{References}

1. Vneshnyaya politika i bezopasnost sovremennoy Rossii. 1992-2002. Hrestomatiya v chetyiroh tomah [Foreign policy and security of modern Russia. 1992-2002. Readings in four volumes]. Editor T.A. Shakleina. V. IV. Dokumentyi. Moscow: Moskovskiy gosudarstvennyiy institut mezhdunarodnyih otnosheniy (U) MID Rossii, Rossiyskaya assotsiatsiya mezhdunarodnyih issledovaniy [Documents. Moscow: Moscow State Institute of International Relations (U) of the Ministry of Foreign Affairs of Russia, Russian Association for International Studies], Autonomous Non-Commercial Organization «INO-Tsentr», 2002. 538 p. (in Russian).

2. Gadzhiev K.S. Geopolitika Kavkaza [Caucasus Geopolitics]. Moscow: Mezhdunarodnyie otnosheniya, 2003. 464 p.

3. Evropeyskaya strategiya bezopasnosti. Bezopasnaya Evropa v luchshem mire. Lyuksemburg: Byuro ofitsialnyih publikatsiy Evropeyskih Soobschestv [European security strategy. Safe Europe in a better world. Luxembourg: Office for Official Publications of the European Communities], 2009. 43 p. (in Russian).

4. Evropeyskiy Soyuz v XXI veke: vremya ispyitaniy [The European Union in the 21st Century: time for a test]. ed. O.Y. Potemkinoy. Response ed. N.Y. Kaveshnikova, N.B. Kondratevoy. Moscow: Ves Mir, 2012. 656 p. (in Russian).

5. Evropeyskiy Soyuz na poroge XXI veka: vyibor strategii razvitiya // pod red. Yu.A. Borko i O.V. Butorinoy. M.: Editorial URSS, 2001. 472 p. (in Russian).

6. ES - Turtsiya: tyazhelyiy son ob integratsii [EU - Turkey: a hard dream about integration]. Radio «Svoboda». November 21, 2013.

Available at: https://www.svoboda.org/a/25174310.html (access date: 11.04.2018).

7. Zabelin S.A. Politika ES v otnoshenii postsovetskih stran Prichernomorya // Bolshoe Prichernomore: protivorechiya i strategicheskie resheniya dlya Rossii [EU policy towards the post-Soviet Black Sea countries. Big Black Sea Coast: Contradictions and Strategic Decisions for Russia]. ed. A.A. Yazkovoy. Dokladyi Instituta Evropyi RAN.No. 324. Moscow: IE RAN, 2016 (in Russian).

8. Zabelin S.A. Stranyi Prichernomorya v kontekste evropeyskoy politiki sosedstva [Black Sea countries in the context of the European Neighborhood Policy]. European Geopolitical Forum. July 13, 2010. Available at: http://gpf-europe.ru/upload/iblock/34c/prichinyvozniknovenya-zeli-politiky-evropejskogo-soseda.pdf (access date: 12.04.2018).

9. Kolobov O.A., Krasnov D.V. «Chernomorskaya sinergiya» Evropeyskogo Soyuza kak novaya initsiativa regionalnogo sotrudnichestva. Vestnik Nizhegorodskogo universiteta im. N.I. Lobachevskogo ["Black Sea Synergy" of the European Union as a new initiative of regional cooperation. Review of the Nizhny Novgorod University. N.I. Lobachevsky]. 2009. No. 2. pp. 201-204 (in Russian).

10. Kontseptsiya vneshney politiki Rossiyskoy Federatsii [The concept of foreign policy of the Russian Federation]. 2008. Available at: http://www.kremlin.ru/acts/news/785 (access date: 03.04.2018).

11. Kontseptsiya vneshney politiki Rossiyskoy Federatsii [The concept of foreign policy of the Russian Federation]. 2013. Available at: http://www.mid.ru/foreign_policy/official_documents/asset_publisher/CptlCkB6BZ29/content/id/122186 (access date: 03.04.2018). 
12. Kontseptsiya vneshney politiki Rossiyskoy Federatsii [The concept of foreign policy of the Russian Federation]. 2016. Available at: http:// www.mid.ru/foreign_policy/news/lasset_publisher/cKNonkJE02Bw/content/id/2542248 (access date: 03.04.2018).

13. Rossiya - Evropeyskiy Soyuz: na puti k chetyiryom obschim prostranstvam. Dokladyi Instituta Evropyi [Russia - European Union: on the way to four common spaces. Reports of the Institute of Europe]. In 2 parts. P. 1. No. 224; Part 2. No. 225. ed. D.A. Danilova. Moscow: Russkiy suvenir, 2008 (in Russian).

14. Sarkozi. Turtsii net mesta v ES [Turkey has no place in the EU]. Izdatelskiy dom «Kommersant». January 14, 2007.

15. Hafizoglu $R$. Turtsiyu ne interesuet vopros vstupleniya v ES - president [Turkey is not interested in the issue of joining the EU - President]. News agency «Trend». January 24, 2015. Available at: https://www.trend.az/world/turkey/2356772.html (access date: 14.04.2018).

16. Uznarodov I.M. Zapad posle Vtoroy mirovoy voynyi: tendentsii razvitiya [West after World War II: Development Trends]. Rostov-on-Don: publisher SKNTs VSh YuFU, 2014. 264 p. (in Russian).

17. Chislo zaderzhannyih posle myatezha v Turtsii uvelichilos do 26 tyis chelovek [The number of detainees after the insurgency in Turkey increased to 26 thousand people]. Rosbizneskonsalting. August 4, 2016. Available at: https://www.rbc.ru/rbcfreenews/57a264db9a794779a4ef7716?from=newsfeed (access date: 11.04.2018).

18. Shmelyov N.P., Fyodorov V.P. Evrosoyuz - Rossiya: mera sotrudnichestva. Dokladyi Instituta Evropyi RAN [EU - Russia: a measure of cooperation. Reports of the Institute of Europe, RAS]. No. 275. Moscow: Russkiy suvenir, 2012. 58 p. (in Russian).

19. Shryoder G. Resheniya. Moya zhizn v politike: per. s nem [Solutions. My life in politics: translated from German]. Moscow: Evropa, 2007. 552 p. (in Russian).

20. Black Sea Synergy. A New Regional Cooperation Initiative. Brussels, 11.04.2007. Available at: http://ec.europa.eu/world/enp/pdf/com07_160_en.pdf (access date: 4.04.2018).

21. Council of the European Union. Joint Declaration of the Prague Eastern Partnership Summit. Prague, 7 May 2009. Brussels, 7 May 2009. 8435/09 (Presse 78), 11 p.

22. Declaration on the Occasion of the Fifteenth Anniversary Summit of the Black Sea Economic Cooperation. Istanbul, 25.06.2007. Available at: http://www. bsecorganization.org/documents/declaration/summit/Reports/Istanbul\%202007.pdf (access date: 16.04.2018).

23. European Neighbourhood Policy. Strategy Paper. Brussels, 12.05.2004. COM (2004) 373 final. $35 \mathrm{p}$.

24. European Parliament Resolution of 20 January 2011 on an EU Strategy for the Black Sea $-2010 / 2087 /($ INI).

Available at: http://www.europarl.europa.eu/sides/getDoc.do?type=TA\&reference=P7TA-2011-0025\&language=HR (access date: 05.04.2018).

25. La vittoria della Russia e il nuovo concerto delle nazioni. Limes. 2017. №2. Available at: http://karaganov.ru/content/images/uploaded/44fbfe8472ad2240e43a8b3b9072da08.pdf (access date: 17.04.2018).

26. Shared Vision, Common Action: A Stronger Europe. A Global Strategy for the European Union's Foreign and Security Policy. Brussels, 2016. Available at: https://eeas.europa.eu/sites/eeas/files/eugs_review_web.pdf (access date: 09.04.2018).

27. The EU Global Strategy: Implications for Russia / Institute of Europe, Russian Academy of Sciences; Egmont - The Royal Institute for International Relations. Ed. by Olga Potemkina. Moscow, 2017. 90 p. 